\title{
ІННОВАЦІЙНІ НАПРЯМИ ПІДВИЩЕННЯ КОНКУРЕНТОСПРОМОЖНОСТІ ПРОДУКЦІЇ ХЛІБОПЕКАРСЬКОЇ ПРОМИСЛОВОСТІ НА ОСНОВІ ВИКОРИСТАННЯ АВС-ХYZ-АНАЛІЗУ
}

\author{
INNOVATIVE DIRECTIONS OF INCREASING THE COMPETITIVENESS \\ OF THE BAKERY INDUSTRY-BASED PRODUCTS \\ USE OF ABC-XYZ-ANALYSIS
}

Лагодієнко В. В.

доктор економічних наук, професор, завідувач кафедрою маркетингу, підприємництва і торгівлі, Одеська національна академія харчових технологій ORCID ID: 0000-0001-9768-5488

Козак К. Б.

доктор економічних наук, доцент, професор кафедри менеджменту та логістики, Одеська національна академія харчових технологій ORCID ID: 0000-0002-8099-6607

Булюк В. В. доктор економічних наук, доцент, Чорноморська митниця Державної митної служби України ORCID ID: 0000-0001-5589-4847

Volodymyr Lagodiienko Doctor of Economics, Professor, Head of the Department of Marketing, Entrepreneurship and Trade, Odessa National Academy of Food Technologies

Katerina Kozak

Doctor of Economics, Associate Professor, Professor of Management and Logistics, Odessa National Academy of Food Technologies

Vitaliy Bulyuk

Doctor of Economics, Associate Professor, Black Sea Customs of the State Customs Service of Ukraine

В статmі обгрунтовано необхідність використання інноваційних підходів до розробки напрямів підвищення конкурентоспроможності продукції хлібопекарської промисловості. Виходячи зі специфіки об'єкта дослідження, основним методом, на використанні якого грунтуються сфрормульовані висновки та пропозиції, $є$ ABC-XYZ-аналіз. Застосування даної методики базується на проведенні трьох етапів: ABC-аналізу, XYZ-аналізу та комбінації результатів цих двох етапів у матриці. 3 використанням інструментарію ABC-XYZ-аналізу проаналізовано асортиментний склад продукції галузі з метою виявлення лідерів та аутсайдерів за критеріями частки у виручці та рівня прогнозованості та стабільності попиту. Розроблено рекомендації щодо використання інноваційних рішень у виробленні напрямів підвищення конкурентоспроможності окремих товарних груп, що дозволятиме здобувати нові конкурентні переваги та покращувати позиції на внутрішніх та зовнішніх ринках. Ключові слова: конкурентоспроможність продукції, хлібопекарська промисловість, інноваційні рішення, інновації, АBC-XYZ-аналіз.

В статье обоснована необходимость использования инновационных подходов к разработке направлений повышения конкурентоспособности продукции хлебопекарной промышленности. Исходя из специфики объекта исследования, основным методом, на котором основаны сфрормулированные выводы и предложения, является ABC-XYZ-анализ. Применение данной методики основано на проведении трех этапов: ABC-анализа, XYZ-анализа и комбинации результатов этих двух этапов в матрице. C использованием инструментария ABC-XYZ-анализа проанализирован ассортиментный состав продукции отрасли с целью выявления лидеров и аутсайдеров по критериям доли в выручке и уровня прогнозируемости и стабильности спроса. Разработаны рекомендации по использованию инновационных решений в выработке направлений повышения конкурентоспособности отдельных товарных групп, что позволит по- 
лучать новые конкурентные преимущества и улучшать позиции на внутренних и внешних рынках. Ключевые слова: конкурентоспособность продукции, хлебопекарная промышленность, инновационные решения, инновации, ABC-XYZ-анализ.

The competitiveness of the industry is influenced by many internal and external factors, including market conditions, purchasing power, food preferences and consumer traditions, the ability to adapt to changes in consumer preferences, technical equipment, production technologies and more. The article substantiates the need to use innovative approaches to developing ways to increase the competitiveness of bakery products. Dynamically competition in the market, requires the development of new technologies, the introduction of new strategies. It is substantiated that the development of new, original approaches to developing a strategy to increase competitiveness, the use of innovative solutions in the activities of bakery enterprises becomes a necessary condition for ensuring an intensive type of development and maintaining a high competitive position in the market. Based on the specifics of the object of study, the main method on which the formulated conclusions and proposals are based is $A B C-X Y Z$-analysis. The application of this technique is based on three stages: $A B C$ analysis, $X Y Z$ analysis and a combination of the results of these two stages in the matrix. Using the tools of $A B C-X Y Z$ analysis, the product range of the industry was analyzed in order to identify leaders and outsiders by the criteria of share in revenue and the level of predictability and stability of demand. Recommendations for the use of innovative solutions in developing ways to increase the competitiveness of individual product groups, which will gain new competitive advantages and improve positions in domestic and foreign markets. It is established that for products of product groups, which are characterized by instability, unpredictability of sales and a small share of revenue, the most appropriate types of innovative transformations such as modification, differentiation and rebranding, as well as marketing innovations. Such changes will help shift those product groups that are disadvantaged by the $A B C-X Y Z$ analysis to higher categories, which will generally increase the competitive advantage of the industry in domestic and foreign markets. Key words: product competitiveness, bakery industry, innovative solutions, innovations, $A B C-X Y Z$-analysis.

Постановка проблеми. Стратегічна важливість хлібопекарської промисловості в економіці України зумовлюється її винятковим статусом у гарантуванні продовольчої безпеки та життєзабезпеченні суспільства. В галузі виробляється продукція, що є предметом першої необхідності та споживається всіма категоріями населення, незалежно від рівня доходів та соціального статусу. Поряд з цим, хлібопекарська галузь є складовою переробної промисловості АПК, що зумовлює ії вагоме значення у забезпеченні функціонування ринку продукції зерновиробництва. Частка галузі в загальному обсязі валової продукції харчової промисловості становить понад 15\%, основні фронди займають близько 8\% [1].

На конкурентоспроможність продукції галузі здійснює вплив багато внутрішніх та зовнішніх чинників, серед яких: ринкова кон'юнктура, купівельна спроможність населення, харчові уподобання та традиції споживачів, здатність вчасно адаптуватись до змін в уподобаннях споживачів, технічна оснащеність, технології виробництва тощо. Останні тенденції розвитку хлібопекарської промисловості засвідчують, що підприємствам галузі, зокрема тим, що мають великі потужності виробництва, дедалі складніше утримувати конкурентні позиції внаслідок значної мінливості умов конкурентної боротьби й зростання вимог до асортименту та якості продукції. Тому вироблення нових, оригінальних підходів до вироблення стратегії підвищення конкурентоспроможності, використання інноваційних рішень у діяльності хлібопекарських підприємств стає необхідною умовою забезпечення інтенсивного типу розвитку та утримання високих конкурентних позицій на ринку.
Аналіз останніх досліджень і публікацій. Проблеми функціонування хлібопекарської промисловості входять до кола наукових інтересів значної кількості дослідників. Серед останніх ґрунтовних публікацій, в яких висвітлюються напрями розвитку галузі, слід виокремити праці Сичевського М. П. і Коваленка О. В. [2], в яких характеризуються основні тенденції розвитку хлібопекарської галузі та чинники, що гальмують ії̈ ефективний розвиток, пропонуються напрями їх вирішення. Теоретичні та прикладні основи формування конкурентної стратегії підприємств на ринку хлібобулочних виробів з акцентом на різновиди стратегічної орієнтації та асортиментної політики хлібопекарських підприємств обґрунтовуються в монографрії Деркачової В. В. [3]. Наявність високого рівня змінюваності конкурентного становища хлібопекарських підприємств, що вимагає максимальної концентрації зусиль підприємств на активному створенні, підтримці та розвитку конкурентних переваг через формування успішних стратегій, констатує Ліщинська В. В. [4, с. 7]. Дурбалова Н. І. [5] зосереджує увагу на значенні інвестиційно-інноваційних процесів в підвищенні конкурентоспроможності хлібопекарського виробництва, пропонує інноваційні підходи в розробці нових видів продукції поліпшеної якості на основі регулювання біотехнологічних процесів. В працях науковців обґрунтовується важливе значення інноваційної орієнтації при розробці шляхів розширення асортименту хлібобулочної продукції [6]. Проведене дослідження ґрунтується на існуючих наукових положеннях, викладених в зазначених розробках, та передбачає вироблення нових підходів до підвищення конкурентоспроможності продукції хлібопекарської промисловості на інно- 
ваційних засадах.

Формулювання цілей статті (постановка завдання). Метою статті є обґрунтування інноваційних напрямів підвищення конкурентоспроможності продукції хлібопекарської промисловості на основі використання ABC-XYZ-аналізу її асортиментного складу.

Виклад основного матеріалу дослідження. В основі АВС-аналізу лежить запропонований В. Парето принцип, відповідно до якого $80 \%$ результату забезпечується використанням 20\% ресурсів. Це інструмент, який дозволяє дослідити товарний асортимент за окремими категоріями продукції, згрупувавши їх за певним критерієм. Це дозволяє виділити коло видів продукції, які забезпечують максимальний ефект: найбільшу виручку чи прибуток. Метою проведення такого аналізу є вироблення рішень щодо ліквідації малорентабельних видів діяльності або ж впровадження заходів з підвищення їхньої конкурентоспроможності. Слід зауважити, що часткові границі категорій є індивідуальними для окремих організацій, зумовлені специфрікою виробництва і залежать від певної сукупності чинників. На практиці було встановлено, що в переважній більшості виробничих і комерційних структур до категорії А належать від 10\% до 20\% позицій, які забезпечують $75-80 \%$ виручки; категорії В - 20-30\% (питома вага у виручці становить 10-15\%); група С включає 60-70\% усіх позицій продукції, яку виробляють підприєм- ства, сумарна частка у виручці - 5-10\% [7, с. 242].

XYZ-аналіз - математично-статистичний метод, який дає змогу проаналізувати і спрогнозувати стабільність продажів окремих видів товарів і коливання рівня споживання тих чи інших товарів [8, с. 50]. Використання цієї методики передбачає розподіл товарів на три групи, виходячи зі значень коефіцієнта варіації - відносного показника, який характеризує мінливість обраної ознаки. 3 метою забезпечення достовірності кількість досліджуваних періодів має бути не менше трьох (в даному дослідженні аналіз проводиться за 5 років). Згідно з методикою, класифрікація здійснюється наступним чином: група $\mathrm{X}$ - об'єкти з високим рівнем стабільності та можливістю точного прогнозування (значення коефріцієнта варіації до 10\%); група Y - об'єкти із середнім рівнем стабільності та середньою ймовірністю прогнозування (значення коефріцієнта варіації від 0\% до 25\%); група Z- нестабільні об'єкти з низьким рівнем прогнозованості (значення коефріцієнта варіації понад $25 \%$ ) [9, с. 142].

Наведені методи найчастіше використовуються науковцями окремо, однак в деяких дослідженнях [10; 11] рекомендується застосовувати обидва види аналізу в комплексі. Згідно з методикою ABC-XYZ-аналізу, аналізовані об'єкти розподіляються на дев'ять блоків залежно від частки у виручці (ABC) та стабільності продажів (XYZ) за допомогою матриці (табл. 1).

Таблиця 1

Матриця характеристик груп об'єктів за результатами ABC-XYZ-аналізу

\begin{tabular}{|c|c|c|c|}
\hline Групи & $x$ & $Y$ & $\mathbf{Z}$ \\
\hline $\mathbf{A}$ & \begin{tabular}{|l|} 
AX \\
Висока прибутковість \\
Регулярність продажів \\
Високий рівень прогнозова- \\
ності \\
\end{tabular} & \begin{tabular}{|l|} 
AY \\
Середня прибутковість \\
Регулярність продажів \\
Високий рівень прогнозованості
\end{tabular} & $\begin{array}{l}\text { AZ } \\
\text { Низька прибутковість } \\
\text { Регулярність продажів } \\
\text { Високий рівень прогнозованості }\end{array}$ \\
\hline B & \begin{tabular}{|l|} 
BX \\
Висока прибутковість \\
Періодичність продажів \\
Середній рівень прогнозова- \\
ності \\
\end{tabular} & \begin{tabular}{|l|} 
ВY \\
Середня прибутковість \\
Періодичність продажів \\
Середній рівень прогнозованості
\end{tabular} & $\begin{array}{l}\text { BZ } \\
\text { Низька прибутковість } \\
\text { Періодичність продажів } \\
\text { Середній рівень прогнозованості }\end{array}$ \\
\hline C & \begin{tabular}{|l|} 
CX \\
Висока прибутковість \\
Нерегулярність продажів \\
Низький рівень прогнозова- \\
ності
\end{tabular} & \begin{tabular}{|l} 
CY \\
Середня прибутковість \\
Нерегулярність продажів \\
Низький рівень прогнозованості
\end{tabular} & $\begin{array}{l}\text { CZ } \\
\text { Низька прибутковість } \\
\text { Нерегулярність продажів } \\
\text { Низький рівень прогнозованості }\end{array}$ \\
\hline
\end{tabular}

Джерело: [12, с. 364 ]

Результати проведеного розподілу використовуються з метою виявлення лідерів та аутсайдерів в асортиментному складі продукції підприємства (галузі) та вироблення необхідних рішень з підвищення конкурентоспроможності кожної з груп товарів.

Сучасні тенденції розвитку хлібопекарської промисловості засвідчують наявність значної диференціації як за асортиментом, так і за ви- робниками, причому між міні-пекарнями та великими промисловими підприємствами відбувається значна конкурентна боротьба. Дослідження ринку, проведені компанією «Maxriseconsulting» свідчать, що основними гравцями на ринку хліба і хлібопродуктів $€$ вертикально-інтегровані компанії: концерн «Хлібпром», який охоплює 15,6\% ринку хлібопродуктів; ПАТ «Київхліб» (м. Київ) - 13,5\%; група «Lauffer Group» (м. Донецьк) - 13,0\%; TOB 
«ХК «Хлібні інвестиції» (м. Київ)-11,1\%; ТМ «Кулиничі» (м. Харків) - 9,4\%; ТМ «Формула смаку» (м. Кропивницький) - 8,8\%; ТМ «Хлібодар» (м. Запоріжжя) - займає 5,9\% ринку [13]. Однак слід констатувати, що близько 50-60\% ринку поділяють між собою приватні міні-пекарні та пекарні торговельної мережі, близько 7-12\% - припадає на цехи підприємств громадського та швидкого харчування [14, с. 16]. Незважаючи на менший ступінь охоплення ринку, останні займають більш вигідні конкурентні позиції. Причиною цього є можливість швидше реагувати на зміну запитів споживачів та змінювати асортимент продукції, менші витрати на збут, відсутність проблеми недовантажених потужностей.

Аналіз асортиментного складу хлібобулочної продукції показав переважаючу частку хліба пше- ничного (41,9\% ринку), хліб житньо-пшеничний і пшенично-житній займають $31,7 \%$, вироби булочні $-24,8 \%$, хліб житній - 1,1\%, інші види хліба - 0,6\% ринку [13].

Проведення першого етапу дослідження ABC-аналізу - передбачає групування за критерієм частки окремих видів продукції в загальному обсязі продажу. Оскільки асортимент продукції окремих хлібопекарських підприємств може включати декілька сотень позицій, то аналіз доцільно проводити в розрізі товарних груп. 3 цією метою дані про виробництво продукції в хлібопекарській галузі в середньому за п'ять років проранжовано в порядку зменшення значення параметру за рівнем важливості з точки зору доходів від реалізації (табл. 2).

Таблиця 2

ABC-аналіз реалізації продукції хлібопекарської промисловості України в розрізі товарних груп, в середньому за 2015-2019 рр.

\begin{tabular}{|c|c|c|c|c|c|}
\hline $\begin{array}{l}\text { № } \\
3 / n\end{array}$ & Вид продукції & $\begin{array}{c}\text { Виручка від } \\
\text { реалізації } \\
\text { продукції, } \\
\text { тис. грн }\end{array}$ & $\begin{array}{c}\text { Частка в } \\
\text { структурі } \\
\text { виручки від } \\
\text { реалізації, \% } \\
\end{array}$ & $\begin{array}{l}\text { Кумулятивна } \\
\text { частка, \% }\end{array}$ & Група \\
\hline 1 & $\begin{array}{l}\text { Хліб та вироби хлібобулочні, нетривалого } \\
\text { зберігання }\end{array}$ & 11481737,5 & 44,30 & 44,30 & A \\
\hline 2 & Печиво солодке & 3879507,6 & 14,97 & 59,26 & A \\
\hline 3 & $\begin{array}{l}\text { Торти і вироби кондитерські; вироби хлібо- } \\
\text { булочні інші }\end{array}$ & 3700573,5 & 14,28 & 73,54 & A \\
\hline 4 & $\begin{array}{l}\text { Печиво солодке, вафрлі та вафельні облат- } \\
\text { ки, покриті шоколадом або іншими суміша- } \\
\text { ми, що містять какао }\end{array}$ & 1317194,0 & 5,08 & 78,62 & B \\
\hline 5 & $\begin{array}{l}\text { Печиво (крім покритого шоколадом або ін- } \\
\text { шими сумішами, що містять какао, печива } \\
\text { солодкого, вафель та вафельних облаток) }\end{array}$ & 1262750,5 & 4,87 & 83,49 & B \\
\hline 6 & $\begin{array}{l}\text { Сухарі, сушки, грінки та вироби подібні під- } \\
\text { смажені }\end{array}$ & 1249443,6 & 4,82 & 88,31 & B \\
\hline 7 & $\begin{array}{l}\text { Вафрлі та вафельні облатки (крім покритих } \\
\text { шоколадом або іншими сумішами, що міс- } \\
\text { тять какао) }\end{array}$ & 1232252,6 & 4,75 & 93,07 & B \\
\hline 8 & Вироби макаронні неварені & 775209,6 & 2,99 & 96,06 & $\mathrm{~B}$ \\
\hline 9 & Пряники та вироби подібні & 772022,3 & 2,98 & 99,04 & $\mathrm{~B}$ \\
\hline 10 & $\begin{array}{l}\text { Вироби хлібобулочні без додавання підсо- } \\
\text { лоджувальних речовин }\end{array}$ & 88609,2 & 0,34 & 99,38 & C \\
\hline 11 & Хлібці хрусткі & 88534,3 & 0,34 & 99,72 & $\mathrm{C}$ \\
\hline 12 & $\begin{array}{l}\text { Продукти, одержані шляхом екструзії чи } \\
\text { розпушування тіста, з прянощами чи со- } \\
\text { лоні }\end{array}$ & 39909,2 & 0,15 & 99,87 & C \\
\hline 13 & Хліб з тіста недріжджового (маца) & 20186,9 & 0,08 & 99,95 & $C$ \\
\hline 14 & $\begin{array}{l}\text { Вироби макаронні із вмістом яєць неваре- } \\
\text { ні }\end{array}$ & 12472,2 & 0,05 & 100,00 & C \\
\hline
\end{tabular}

Джерело: розраховано автором за даними [15]

Позиції, що віднесені до групи А - це продукція, що забезпечує до 80\% загальної виручки від продажу. Товари цієї групи мають найвищу конкурентоспроможність, водночас навіть при незначному її зниженні підприємства будуть нести великі втрати. До такої категорії в хлібопекарській промисловості належать хліб, хлібобулочні виро- би, печиво солодке, торти і кондитерські вироби. Виробництво та збут зазначеної продукції має відбуватись під жорстким контролем, на її виробництво спрямовуються найбільші інвестиції. До групи В входять товари, які забезпечують стабільні продажі та спроможні конкурувати на ринку з іншими видами хлібопекарської продукції. До групи С на- 
лежать позиції, які забезпечують отримання менше $1 \%$ виручки. Це вироби, які не мають значного впливу на результати діяльності, забезпечуючи потреби малочисельних груп споживачів.

Використовуючи метод дотичної, можна проілюструвати відсоткове співвідношення груп (рис. 1).

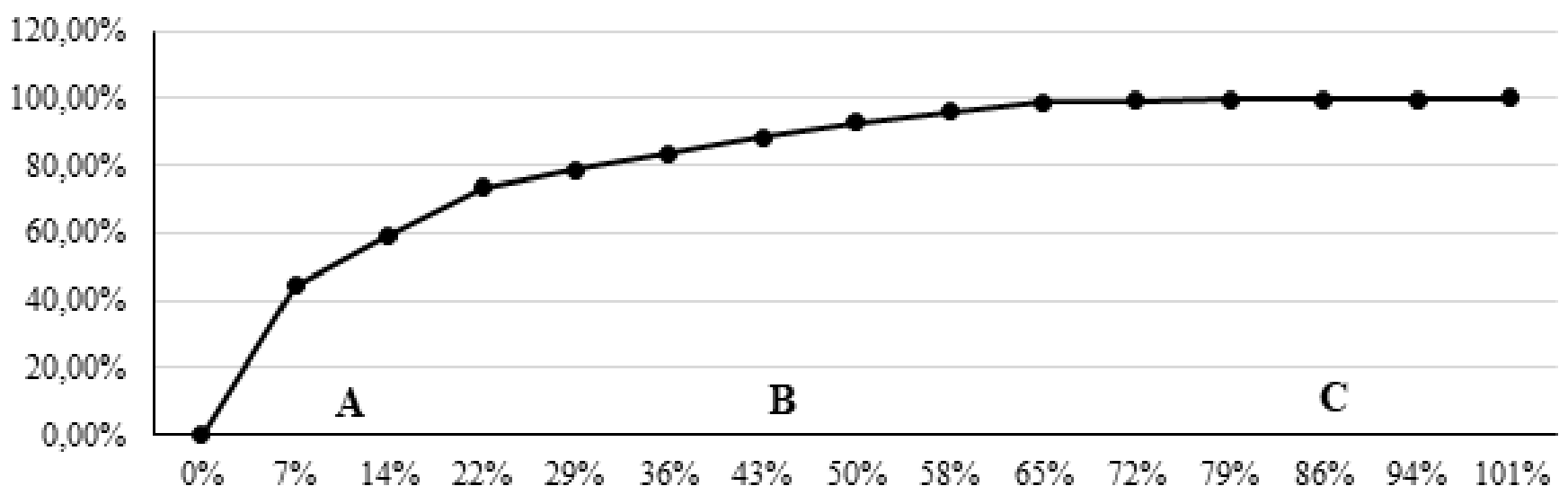

Рис. 1. Розподіл товарних груп хлібопекарської продукції на групи $A, B, C$ використанням методу дотичної (АВС-крива)

Джерело: побудовано автором

Підсумовування результатів ABC-аналізу засвідчує, що найбільшу кількість позицій віднесено до групи В (6 товарних груп), до групи А ввійшло лише 3 товарних групи (табл. 3).

Результати проведеного аналізу свідчать про те, що лише 21,4\% позицій забезпечують 73,5\% всієї виручки від реалізації продукції, а більше, ніж третина товарних груп - лише 1\%. Збільшення виробництва видів продукції, що належать до груп А та В буде призводити до зростання доходів.

Таблиця 3

Зведені результати АВС-аналізу продукції хлібопекарської промисловості

\begin{tabular}{|c|c|c|c|c|}
\hline Група & $\begin{array}{c}\text { Виручка від } \\
\text { реалізації, } \\
\text { тис. грн }\end{array}$ & Частка, \% & $\begin{array}{c}\text { Кількість } \\
\text { позицій }\end{array}$ & Частка, \% \\
\hline А & 19061818,6 & 73,5 & 3 & 21,4 \\
\hline В & 6608872,7 & 25,5 & 6 & 42,9 \\
\hline С & 249711,8 & 1,0 & 5 & 35,7 \\
\hline Всього & 25920403,1 & 100 & 14 & 100 \\
\hline
\end{tabular}

Джерело: розраховано автором

Основним недоліком АBC-аналізу є неврахування коливань попиту, тому для його усунення доцільно комбінувати цей метод з проведенням XYZ-аналізу, відповідно до якого товари групуються за значенням коефріцієнта варіації (критерії розподілу було деталізовано раніше). Результати XYZ-аналізу асортиментного складу продукції хлібопекарської галузі показали відсутність товарних груп, що характеризуються стабільним попитом та мають високу можливість прогнозування (табл. 4).

Поєднання ABC- та XYZ-аналізу дозволяє розподілити всі види товарів на дев'ять груп за впливом на виручку та стабільністю і можливістю прогнозування попиту, сформувавши відповідну матрицю (табл. 5).

Слід констатувати, що товарні групи, які б займали позицію $\mathrm{AX}$ - найвигіднішу серед інших,відсутні. Для цієї категорії характерними є стабільність продажів та незначні коливання попиту, це товари, які могли б мати найвищу конкурен- тоспроможність та забезпечувати гарантоване надходження коштів. Однак наявні товарні групи, що віднесені до категорії АY. До них належать товари, що користуються найбільшим попитом, який має середню прогнозованість, та забезпечують отримання найвищої частки в загальному обсязі продажу. Також велика частина продукції потрапила до категорій BY та BZ, попит на які недостатньо стабільний та прогнозований, що вимагає проведення додаткових заходів з підвищення конкурентоспроможності.

Зважаючи на те, що, згідно з результатами останніх досліджень ринку хлібобулочних виробів [16], в Україні спостерігається зміна культури споживання хліба і споживчих переваг з орієнтацією на дотримання здорового способу життя, можна передбачити зменшення попиту на товари групи AY, які забезпечують отримання 75-80\% виручки. На це вказують і існуючі тенденції на ринках США, Франції та інших країн [6]. Тому для збереження позицій та, при сприятливому перебігу подій, пе- 
реведення продукції з категорії AY до категорії AX доцільно спрямовувати зусилля на виробництво інноваційних продуктів цих товарних груп: хліба з дієтичними та лікувально-профрілактичними властивостями, збагачених цінними мікро- і макроелементами, вітамінними домішками та наповнювачами. Так, наприклад, Інститутом продовольчих ресурсів НААН удосконалено технологію безглютенових і безбілкових хлібобулочних та кондитерських виробів для осіб, хворих на целіакію й френілкетонурію. Також підвищенню конкурентоспроможності такої продукції сприятиме розробка та впровадження інноваційних технологій, спрямованих на продовження термінів придатності та збереження свіжості хліба, зокрема технологій заморожування хлібопекарської продукції, що дасть змогу зміцнити конкурентні позиції не лише на вітчизняному ринку, а й підвищити експортний потенціал галузі.

Таблиця 4

XYZ-аналіз асортиментного складу продукції хлібопекарської галузі в розрізі товарних груп

\begin{tabular}{|l|c|c|}
\hline \multicolumn{1}{|c|}{ Вид продукції } & $\begin{array}{c}\text { Коефіціснт } \\
\text { варіації, \% }\end{array}$ & $\begin{array}{c}\text { Категорія то- } \\
\text { варної групи } \\
\text { (X, Y, Z) }\end{array}$ \\
\hline Сухарі, сушки, грінки та вироби подібні підсмажені & 11 & Y \\
\hline Пряники та вироби подібні & 12 & Y \\
\hline Хліб та вироби хлібобулочні, нетривалого зберігання & 13 & Y \\
\hline Печиво солодке & 15 & Y \\
\hline Вироби макаронні неварені & 17 & Y \\
\hline Вафрлі та вафельні облатки & 18 & Y \\
\hline $\begin{array}{l}\text { Печиво солодке, вафрлі та вафельні облатки, покриті шоколадом або } \\
\text { іншими сумішами, що містять какао }\end{array}$ & 20 & Ү \\
\hline $\begin{array}{l}\text { Торти і вироби кондитерські; вироби хлібобулочні інші з додаванням } \\
\text { підсолоджувальних речовин }\end{array}$ & 22 & Y \\
\hline Хлібці хрусткі & 31 & $\mathrm{Z}$ \\
\hline $\begin{array}{l}\text { Печиво (крім покритого шоколадом або іншими сумішами, що містять } \\
\text { какао, печива солодкого, вафель та вафрельних облаток) }\end{array}$ & 32 & $\mathrm{Z}$ \\
\hline Вироби хлібобулочні без додавання підсолоджувальних речовин & 44 & $\mathrm{Z}$ \\
\hline Хліб з тіста недріжджового (маца) & 50 & $\mathrm{Z}$ \\
\hline Вироби макаронні із вмістом яєць неварені & 52 & $\mathrm{Z}$ \\
\hline $\begin{array}{l}\text { Продукти, одержані шляхом екструзії чи розпушування тіста, з пряно- } \\
\text { щами чи солоні }\end{array}$ & 57 & \\
\hline
\end{tabular}

Джерело: розраховано автором

Особливий підхід має використовуватись стосовно хлібопекарської продукції, що входить до категорії CZ. Здійснюючи незначний внесок у формування загального обсягу виручки від реалізації, дані товарні групи характеризуються нестабільністю та непрогнозованістю продажу, які доцільно або виводити з асортиментного складу продукції з метою зниження ризику втрат, або ж змінювати стратегію формування конкурентоспроможності таких товарів з метою переміщення їх до інших груп. В умовах динамічності кон'юнктури ринку та зростання рівня конкуренції серед виробників хлібопекарської продукції утримання позицій можливе за умови використання другого підходу, причому його реалізація має базуватись на впровадженні інновацій та модернізації виробництва. Найпростішими інноваційними інструментами є модифікація, диференціація та ребрендинг цих видів продукції. Наприклад, технологія такої товарної групи, як хлібці хрусткі, зазвичай передбачає використання синтетичних харчових домішок та поліпшувачів, що часто негативно відбивається на стані здоров'я споживачів цієї продукції. Одним з інноваційних підходів є використання лікарських та пряно-ароматичних рослин або їх екстрактів для надання ароматичних та смакових властивостей даному виду продукції. Крім продуктових інновацій, для товарів, що ввійшли до категорії CZ, доцільно зосередити увагу на маркетингових інноваціях, наприклад, запровадження нових форм взаємодії зі споживачами, формування асортиментної структури із врахуванням регіональних особливостей: демографічних, кліматичних, екологічних тощо. Такі впровадження безсумнівно сприятимуть збільшенню попиту та підвищенню конкурентоспроможності продукції хлібопекарської промисловості.

Висновки. Важливе соціально-економічне значення хлібопекарської промисловості в гарантуванні продовольчої безпеки ставить високі вимоги до умов функціонування галузі та забезпечення високого рівня конкурентоспроможності її продукції. Ринкові можливості підприємств хлібопекарської промисловості значно розширюються 
Матриця інтегрованого ABC-XYZ-аналізу асортиментного складу продукції хлібопекарської галузі в розрізі товарних груп

\begin{tabular}{|c|c|c|c|}
\hline Групи & $\mathbf{X}$ & $\mathbf{Y}$ & $z$ \\
\hline A & $\begin{array}{l}\text { AX } \\
\text { Немає }\end{array}$ & $\begin{array}{l}\text { AY } \\
\text { Хліб та вироби хлібобулочні, нетривалого } \\
\text { зберігання } \\
\text { Печиво солодке } \\
\text { Торти і вироби кондитерські; вироби хлібо- } \\
\text { булочні інші }\end{array}$ & $\begin{array}{l}\text { AZ } \\
\text { Немає }\end{array}$ \\
\hline B & $\begin{array}{l}\text { BX } \\
\text { Немає }\end{array}$ & $\begin{array}{l}\text { ВY } \\
\text { Печиво солодке, вафрлі та вафеельні облатки, } \\
\text { покриті шоколадом або іншими сумішами, } \\
\text { що містять какао } \\
\text { Сухарі, сушки, грінки та вироби подібні } \\
\text { Вафлі та вафельні облатки } \\
\text { Вироби макаронні неварені } \\
\text { Пряники та вироби подібні } \\
\end{array}$ & \begin{tabular}{|l} 
BZ \\
Печиво (крім покритого шоколадом або \\
іншими сумішами, що містять какао, печива \\
солодкого, вафель та вафельних облаток)
\end{tabular} \\
\hline C & \begin{tabular}{|l|}
$\mathbf{C X}$ \\
Немає
\end{tabular} & $\begin{array}{l}\text { CY } \\
\text { Немає }\end{array}$ & \begin{tabular}{|l}
$\mathbf{C Z}$ \\
Вироби хлібобулочні без додавання підсо- \\
лоджувальних речовин \\
Хлібці хрусткі \\
Продукти, одержані шляхом екструзії чи \\
розпушування тіста, з прянощами чи солоні \\
Хліб з тіста недріжджового (маца) \\
Вироби макаронні із вмістом яєць неварені
\end{tabular} \\
\hline
\end{tabular}

Джерело: розраховано автором

при впровадженні інновацій в їхню діяльність, це дозволяє їм створювати вироби, що мають вищу споживчу цінність та спроможні задовольнити потреби найвибагливіших споживачів. За результатами проведеного аналізу вдалось виявити лідерів та аутсайдерів в асортиментному складі продукції галузі та виробити напрями підвищення конкурентоспроможності окремих товарних груп, які передбачають впровадження інновацій. Рекомендації стосовно продукції, що займає ключові позиції серед інших, спрямовані на врахування тенденцій до зміни споживчих переваг в бік дотримання здорового способу життя, виробництво інноваційних видів хліба з дієтичними та лікувальнопрофрілактичними властивостями, збагачених цінними мікро- і макроелементами, вітамінними домішками та наповнювачами, впровадження інноваційних технологій, спрямованих на продовження термінів придатності та збереження свіжості хлібобулочних виробів. Для продукції товарних груп, які характеризуються нестабільністю, непрогнозованістю продажу та незначною часткою у виручці, найбільш доцільними стануть такі види інноваційних перетворень, як модифрікація, диференціація та ребрендинг, а також маркетингові інновації. Такі зміни сприятимуть переведенню тих товарних груп, які займають невигідні позиції за результатами ABC-XYZ-аналізу, до категорій вищого рангу, що загалом підвищуватиме конкурентні переваги продукції галузі на внутрішніх та зовнішніх ринках.

\section{БІБЛІОГРАФІЧНИЙ СПИСОК:}

1. Виробництво промислової продукції за видами. Державна служба статистики України. URL : http://www. ukrstat.gov.ua/operativ/operativ2016/pr/

vr_rea_ovpp/vr_rea_ovpp_u/arh_vppv_u.html

2. Сичевський М. П. Хлібопекарська галузь України: тенденції та проблеми ї̈ розвитку. Економіка АПК. 2018. № 5. C. 14-23.

3. Деркачова В.В. Формування маркетингової стратегії конкурентоспроможності підприємств АПК у сучасних умовах : монографія. Луганськ: Елтон-2, 2010. 234 с.

4. Ліщинська В. В. Аналіз конкурентного середовища хлібопекарської промисловості України. Ефективна економіка. 2018. № 4. URL: http://www.economy.nayka.com.ua/pdf/4_2018/163.pdf.

5. Дурбалова Н. І. Інноваційно-інвестиційний вектор розвитку хлібопекарських підприємств. Економіка харчової промисловості. 2019. № 3. С. 66-72.

6. Лагодієнко В. В., Завгородній А. В., Шаповалова І. О. Технологічні інновації в забезпеченні конкурентоспроможності підприємств харчової промисловості. Вісник Хмельницького національного університету. Економічні науки. 2020, № 6. С. 291-397.

7. Хаврук В. О. Методи визначення номенклатурних груп в АВС-аналізі. Вісник Національного транспортного університету. 2015. № 3. С. 239-253. URL : http://nbuv.gov.ua/UJRN/Vntu_2015_3_34. 
8. Бодряков Р. АВС-анализ для повышения эффрективности работы склада. Пошаговое описание методики. Логистик \& система. 2008. № 1. URL : http://www.rombcons.ru.logistikl.htm.

9. Вініченко О. М. Методика визначення ступеня важливості та стабільності критеріїв ефективності системи контролю соціально-економічного розвитку підприємства на основі ABC- і XYZ-аналізу. Бізнес Інформ. 2016. № 2. C. 149-159. URL: https://www. business-inform.net/export_pdf/business-inform2016-2_0-pages-149_159.pdf.

10. Ваховська М.Ю. АВС-аналіз як сучасний логістичний інструмент: особливості та сорера застосування. Вісник Національного університету «Львівська політехніка». 2007. № 580. C. 23-27. URL : http :// ena .Ip.edu .ua.

11. Тюленєва Ю.В. Застосування методу АВС-XYZ-аналізу під час управління логістичними процесами аграрного підприємств. Глобальні та національні проблеми економіки. 2017. № 20. C. 598-603. URL: http:// global-national.in.ua/archive/20-2017/122.pdf.

12. Окрепкий P. Методичні аспекти інтеграції АBC- і XYZ-аналізу в процесі фрормування асортиментного портфеля фірми. Наука молода. 2011. № 15. С. 362-366.

13. Навольская Н. В. Исследование рынка хлеба и хлебобулочных изделий Украины. 2016. URL:https:// maxrise-consulting.com/analiz-rynka-hleba/

14. Сичевський М. П., Васильченко О. М., Коваленко О. В. Хлібопекарська галузь України: тенденції та проблеми ії розвитку. Економіка АПК. 2018. № 5. C. 14-23. URL: http://nbuv.gov.ua/UJRN/E_apk_2018_5_4.

15. Реалізація промислової продукції за видами за переліком PRODCOM. Державна служба статистики України. URL: http://www.ukrstat.gov.ua.

16. Аналіз ринку хлібобулочних виробів України. 2020 рік. URL : https://pro-consulting.ua/ua/issledovanierynka/analiz-rynka-hlebobulochnyh-izdelij-2020.

17. Сичевський М. П., Куць О. І., Савицький Е. Е., Семенівська О. А. Діючі об’єкти інтелектуальної власності Інституту продовольчих ресурсів НААН. Київ: Аграрна наука, 2020. 24 с.

\section{REFERENCES:}

1. Vyrobnytstvo promyslovoi produktsii za vydamy. [Production of industrial products by type]. Derzhavna sluzhba statystyky Ukrainy. (in Ukrainian) Available at http://www.ukrstat.gov.ua/operativ/operativ2016/pr/vr_rea_ovpp/vr_ rea_ovpp_u/arh_vppv_u.html.

2. Sychevsky, M.P. (2018). Khlibopekarska haluz Ukrainy: tendentsii ta problemy yii rozvytku. [Baking industry of Ukraine: trends and problems of its development]. Ekonomika APK - Economics of agro-industrial complex, No. 5. pp. 14-23. (in Ukrainian).

3. Derkachova, V.V. (2010). Formuvannia marketynhovoi stratehii konkurentospromozhnosti pidpryiemstv APK u suchasnykh umovakh : monohrafiia [Formation of marketing strategy of competitiveness of agro-industrial enterprises in modern conditions: monograph]. Lugansk: Elton-2. 234 p. (in Ukrainian).

4. Lishchynska, V.V. (2018). Analiz konkurentnoho seredovyshcha khlibopekarskoi promyslovosti Ukrainy [Analysis of the competitive environment of the bakery industry of Ukraine]. Efektyvna ekonomika - Efficient economy. No. 4. (in Ukrainian). Available at http://www.economy.nayka.com.ua/pdf/4_2018/163.pdf

5. Durbalova, N.I. (2019). Innovatsiino-investytsiinyi vektor rozvytku khlibopekarskykh pidpryiemstv. [Innovation and investment vector of development of bakery enterprises]. Ekonomika kharchovoi promyslovosti - Economics of the food industry. No. 3. pp. 66-72. (in Ukrainian).

6. Lagodiienko, V.V., Zavgorodniy, A.V., Shapovalova, I.O. (2020). Tekhnolohichni innovatsii v zabezpechenni konkurentospromozhnosti pidpryiemstv kharchovoi promyslovosti. [Technological innovations in ensuring the competitiveness of the food industry]. Visnyk Khmelnytskoho natsionalnoho universytetu. Ekonomichni nauky Bulletin of Khmelnytsky National University. Economic sciences. № 6. pp. 291-397. (in Ukrainian).

7. Havruk, V.O. (2015). Metody vyznachennia nomenklaturnykh hrup v AVS-analizi. [Methods for determining nomenclature groups in $\mathrm{ABC}$ analysis]. Visnyk Natsionalnoho transportnoho universytetu - Bulletin of the National Transport University. No. 3, pp. 239-253. (in Ukrainian). Available at http://nbuv.gov.ua/UJRN/Vntu_2015_3_34.

8. Bodryakov, R. (2008). AVS-analiz dlia povysheniya effektivnosti raboty sklada. Poshahovoe opisanie metodiki. [ABC analysis to improve the efficiency of the warehouse. Step-by-step description of the technique]. Lohistyk \& sistema - Logistic \& system. No. 1. (in Russian). Available at http://www.rombcons.ru/logistik2.htm

9. Vinichenko, O.M. (2016). Metodyka vyznachennia stupenia vazhlyvosti ta stabilnosti kryteriiv efektyvnosti systemy kontroliu sotsialno-ekonomichnoho rozvytku pidpryiemstva na osnovi AVS- i XYZ-analizu [Methodology for determining the level of importance and stability criteria for the efficiency of the system and control of social and economic development of an enterprise on the basis of $\mathrm{ABC}$ - and XYZ-analysis]. Biznes Inform - Business Inform. No. 2, pp. 149-159. (in Ukrainian). Available at https://www.business-inform.net/export_pdf/business-inform 2016-2_0-pages-149_159.pdf

10. Vakhovska, M. Yu. (2007). ABC analysis as a modern logistics tool: features and scope. [ABC analysis as a modern logistics tool: features and scope]. Bulletin of the National University «Lviv Polytechnic» - Bulletin of the National University «Lviv Polytechnic». No. 580, pp. 23-27. (in Ukrainian). Available at http: /lena.lp.edu.ua

11. Tyuleneva, Y.V. (2017). Zastosuvannia metodu ABC-XYZ-analizu pid chas upravlinnia lohistychnymy protsesamy ahrarnoho pidpryiemstv. [Application of the ABC-XYZ method - analysis during the management of logistics processes of agricultural enterprises]. Hlobalni ta natsionalni problemy ekonomiky - Global and national economic problems. No. 20, pp. 598-603. (in Ukrainian). Available at http://global-national.in.ua/archive/20-2017/122. 
pdf

12. Okrepky, R. (2011). Metodychni aspekty intehratsii AVS- i XYZ-analizu v protsesi formuvannia asortymentnoho portfelia firmy [Methodological aspects of the integration of $A B C$ and $X Y Z$ analysis in the process of forming the range of the firm]. Nauka moloda - Science is young. No. 15, pp. 362-666. (in Ukrainian).

13. Navolskaya, N.V. (2016). Issledovanie rynka khleba i khlebobulochnykh izdeliy Ukrainy [Research of the market of bread and bakery products of Ukraine]. (in Russian). Available at https://maxrise-consulting.com/analizrynka-hleba/

14. Sychevsky, M.P., Vasylchenko, O.M., Kovalenko, O.V. (2018). Khlibopekarska haluz Ukrainy: tendentsii ta problemy yii rozvytku [Bakery industry of Ukraine: trends and problems of its development]. Ekonomika APK - Economics of agro-industrial complex, No. 5, pp. 14-23. (in Ukrainian). Available at http://nbuv.gov.ua/UJRN/E_ apk_2018_5_4

15. Derzhavna sluzhba statystyky Ukrainy. Realizatsiia promyslovoi produktsii za vydamy za perelikom PRODCOM. [Sales of industrial products by type according to the PRODCOM list]. (in Ukrainian). Available at http://www.ukrstat. gov.ua.

16. Analiz rynku khlibobulochnykh vyrobiv Ukrainy. 2020 rik [Analysis of the bakery market in Ukraine. 2020]. (in Ukrainian). Available at https://pro-consulting.ua/en/issledovanie-rynka/analiz-rynka-hlebobulochnyh-izdelij-2020

17. Sychevsky, M.P., Kuts, O.I., Savitsky, E.E., Semenovskaya, O.A. (2020). Diiuchi obiekty intelektualnoi vlasnosti Instytutu prodovolchykh resursiv NAAN [Existing intellectual property of the Institute of Food Resources of NAAS]. Kyiv: Agrarian Science. 24 p. (in Ukrainian). 